\title{
DEVELOPMENT OF AN AUTOMATIC MARKETPLACE USING VIRTUAL COLLABORATION
}

\author{
Janez Benedičič, Janez Krek, Vilko Leben, Gusztav Velez, Vorös, Tadej Beravs, \\ Simon Potočnik, Roman Žavbi
}

Original scientific pape

New product development is vital for the development of business enterprises and the society where the enterprise operates. The paper presents a case example of an automated marketplace development, which took place in the P-ino d.o.o. company. Developing such a complex product required the participation of experts from different areas, and it included also students, who definitely contributed to greater creativity and openness of the development team. More than $85 \%$ of all the communication within the development team took place in virtual form. Testing of the finished prototype was also more or less virtual. Virtual communication in the development of such a complex product as an automated marketplace proved to be a very suitable method of interpersonal communication within the development team in all development phases of the product. It was particularly efficient because the members of the development team had different skills and were coming from different institutions and companies.

Keywords: communication; industrial application; virtual product development team

Razvoj automatizirane tržnice pomoću virtualne suradnje

Izvorni znanstveni članak Razvoj novog proizvoda od bitne je važnosti za razvoj poslovnih poduzeća i za društvenu zajednicu u kojoj poduzeće djeluje. U radu se daje opis razvoja automatizirane tržnice u poduzeću P-ino d.o.o. Razvoj takvog složenog proizvoda zahtijevao je sudjelovanje stručnjaka iz različitih područja, a također je uključio i studente, koji su sigurno pridonijeli većoj kreativnosti i otvorenosti razvojnog tima. Više od $85 \%$ ukupne komunikacije razvojnog tima odvijao se u virtualnom obliku. Ispitivanje završnog prototipa također je bilo više manje virtualno. Virtualna komunikacija u razvoju tako složenog proizvoda kao što je automatizirana tržnica dokazala se kao vrlo pogodna metoda za međusobnu komunikaciju razvojnog tima u svim razvojnim fazama proizvoda. Bila je posebno učinkovita jer su članovi razvojnog tima posjedovali različite vještine i dolazili iz različitih institucija i poduzeća.

Ključne riječi: industrijska primjena; komunikacija; virtualni tim za razvoj proizvoda

\section{Introduction and motivation}

Farming is no longer so closely connected with the traditional way of life in the countryside; it is increasingly becoming business-oriented. An entrepreneurial spirit and new products are therefore important, especially on small and medium-sized family-owned farms, because the costs of the traditional methods are too high. In Slovenia, farms that use a minimum of 1 ha and a maximum of 6 ha of agricultural land or raise at least 2 and not more than 30 livestock units are considered small and medium-sized farms [1], and stockbreeding is their main agricultural activity. The reorientation or diversification of these farms, which is necessary to strengthen the welfare of rural communities, is taking place too slowly. Recognizing new, profitable opportunities in a systematic way is, therefore, of even greater importance [2].

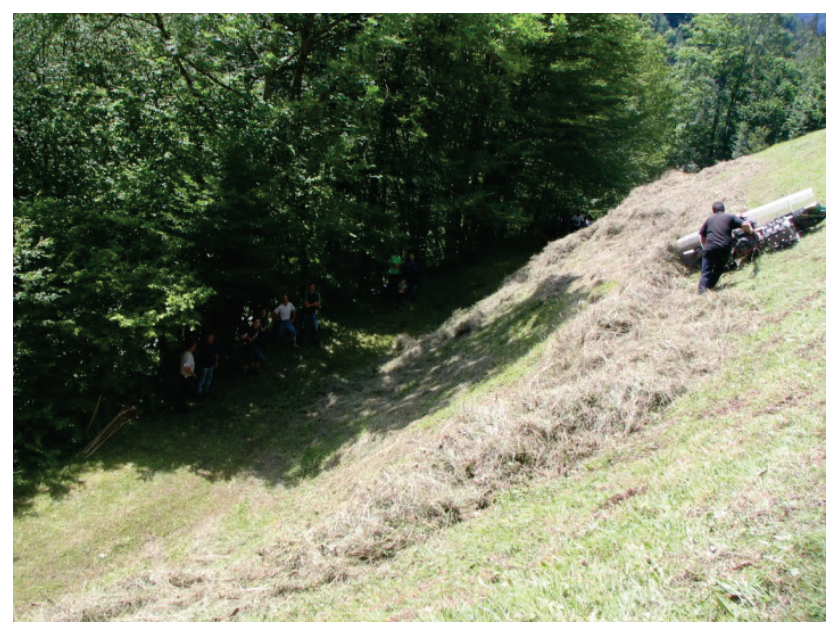

Figure 1 Steep terrain in which grass has to be mown and collected
The first author is a researcher who also became the owner of a mountain farm situated in a hilly area at an altitude of $780 \mathrm{~m}$. The farming conditions there are quite difficult (Fig. 1). Therefore, the farm can be economically viable only if it develops agricultural products having a high economic, nutritional, social and health value.

Using the method of searching for opportunities [2, 3 ], various options were recognized, including milk production with simultaneous maximised use of the natural resources available at the farm. Focusing on milk production will yield products of higher quality, which can be sold at a higher price on the market. In the case of milk, higher quality means hay milk and the use of ecological farming methods. To produce such milk, hay production needs to be adjusted as well, because only high-quality feed ensures cost-effective production of high-quality milk. Another essential aspect of this farm's development is its reorientation towards direct sales (i.e. without any intermediaries), which will enable increased revenues at relatively unchanged costs.

The farm's reorientation is therefore based on the process of feed production and sale of raw hay milk as the basic activity. To perform this process, appropriate technical systems (i.e. products) are needed, namely seeding machines, manure spreaders, mowers, grass transporters, hay drying chamber, hay distributors, milking machines, milk transporters and automatic vending machines (as parts of an automatic marketplace for agricultural products from local farms). The above-mentioned process therefore offers us an opportunity to develop such products.

The paper describes virtual development of automatic milk vending machines and packed agricultural products with emphasis on the percentages of using various types 
of intrateam communication and supporting communication technologies. The decision to develop a new vending machine for milk and packed agricultural products is based on the fact that existing vending machines cannot be integrated in an automatic marketplace. The devised concept of an automatic marketplace is based on modular software (control software and graphical user interface) and a common payment module. Such an automatic marketplace concept enables consumers to order and pay in one place, while farmers can conveniently sell products from their basic and supplementary agricultural activities.

It was decided to use virtual development done by a team that would also include a couple of students, as the authors have had much positive experience with the use of such an approach [4]. For formal reasons, the participating students performed their work outside of their regular study commitments.

This paper is an extended version of the one presented at the DESIGN2014 Conference [5].

\section{Vending machine development process}

A model of the vending machine development process was proposed (Fig. 2). It was later found that the development process in fact consists of a highly simplified Gausemaier's 3-Cycle-Model [6] with emphasized iterative developmental steps.

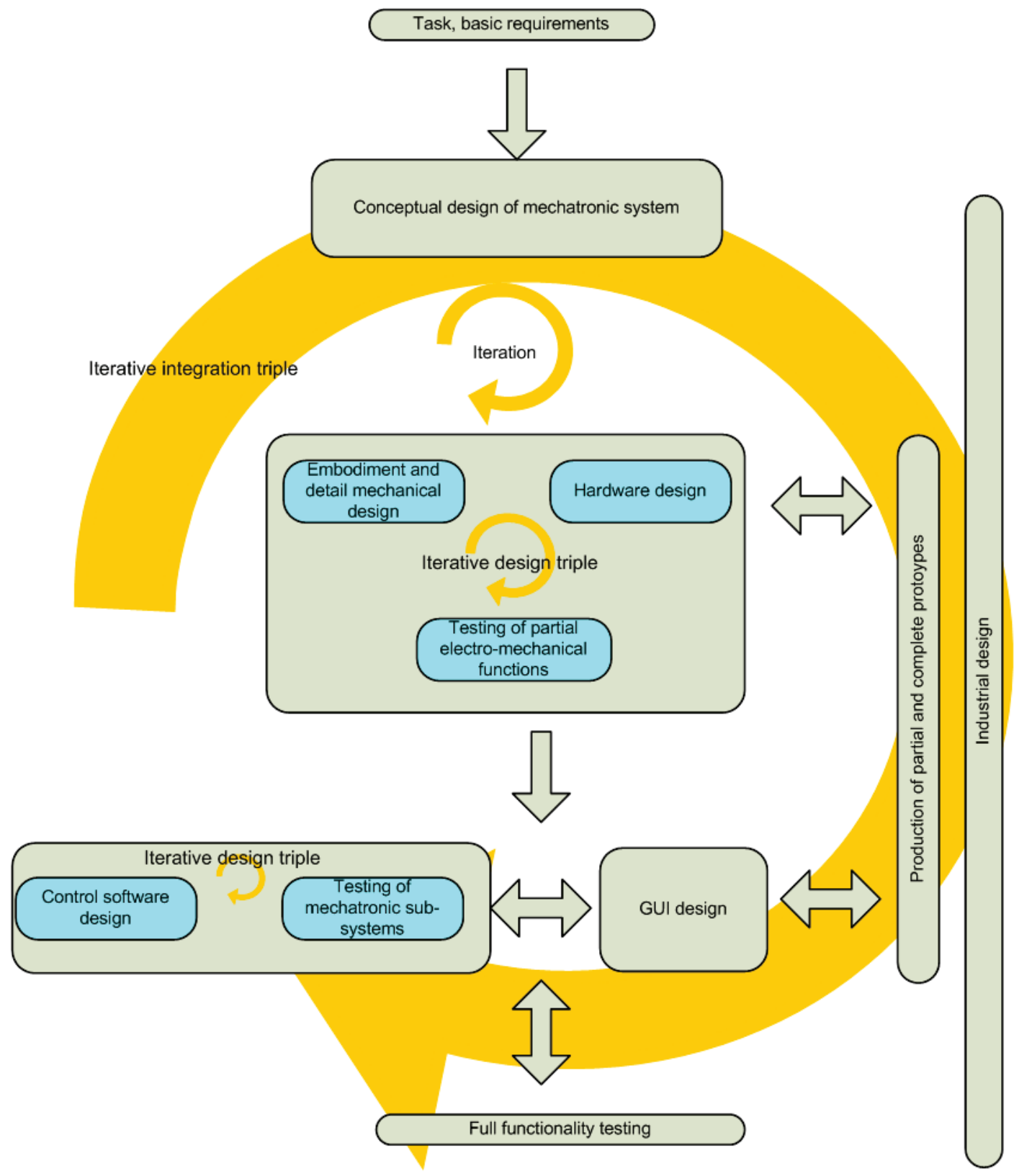

Figure 2 Model of the vending machine development process [5]

\subsection{Task and basic requirements}

The developmental task is based on the results obtained (in our particular case) by using the method of searching for opportunities $[2,3]$. To begin with, in order to perform the process of producing hay and selling hay milk, a vending machine for three types of drinks (raw hay milk, skimmed hay milk and yoghurt) was selected from a set of products. The said vending machine was supposed to enable remote monitoring and interventions, 
and it had to be in line with the concept of automatic marketplace, which is based on modular software (control software and graphical user interface) and a joint payment module.

This was followed by the selection of functions to be performed by individual modules and the generation of alternative principle solutions for these modules. In this phase, the basic structure of control was also designed.

\subsection{Iterative design triple}

The design (embodiment and detail) of individual modules affects their behaviour. Therefore, it is closely associated with testing, while testing is further associated with the manufacture of partial prototypes. This iterative process is characterised by intense cooperation between the members of an interdisciplinary team. Based on the results of testing, it was necessary to make appropriate minor and major changes or even to find principle solutions. All modules were processed in this way.

Subsequently, iterative development of individual modules was done, in the following sequence:

- Development of and searching for (commercially available) mechanical components.

- Development of and searching for (commercially available electrical and electronic components).

- Checking and supplementing of the control process for the mechatronic module.

- Development of a graphical user interface.

- Production of partial prototypes.

- Testing of the behaviour of developed modules.

\subsection{Iterative integration triple}

Through physical and software integration of all modules, the functionality of the entire mechatronic product (i.e. vending machine) has to be achieved. Such integration is followed by comprehensive testing (by system developers and test users), which has to show the actual behaviour of the mechatronic product as a whole. More or less extensive changes and supplements of the individual modules, the controllers and/or the user interface are based on the findings of a thorough analysis of the causes for any differences between the required and actual behaviours.

\section{Team formation}

It is of paramount importance that members of a development team are from the fields which cover all phases of the product being developed (see Table 2). A wide range of knowledge and different viewpoints stimulate team creativity [7] and the end result is a product of a higher quality.

The development of information and communication technologies (ICT) has led to the possibility of forming virtual development teams. These teams are supposed to provide many advantages over traditional ones, including the ability to bridge time and space (e.g. "follow-the-sun" product development), better utilization of distributed human resources without physical relocation of employees, ability to hire the best people regardless of their location, and organizational flexibility, e.g. [8, 9]. The reduced need for constant physical presence means lower development costs and quicker development. There is less face to face communication and more virtual meetings of the team or individual team members; furthermore, experts who for various reasons would find it difficult to participate in usual development teams are able to get involved in teams of this type.

Members of a virtual team can also come from different geographical and cultural settings. Different cultural backgrounds of team members can sometimes prove to be an obstacle due to different views on a problem $[10,11]$. Basically, different views on a problem should add to the team's creativity, but creativity can sometimes be impeded due to disagreements related to the cultural positioning of a new product within a particular environment.

Students also hold a special place in virtual development groups, as they are able to participate in development teams within the framework of their studies and can perform their tasks on an equal basis to other team members. It was already shown in virtual teams composed exclusively of students [12] that virtual communication within a development team does not impair the results of development. Rather, it enables an interdisciplinary approach and participation of students from different cultural, language and social environments [13].

Student collaboration within real-life product development as a concept of product development education provides a good dose of reality and exposes stakeholders to the challenges of the business environment. It also stimulates learning motivation by relating technical knowledge to its applications [14]. This also increases the preparedness of students for assuming developmental tasks directly after the completion of their studies.

\section{Communication in virtual teams}

In a virtual development team (and also in co-located teams), good communication is needed for trust building [15], since trust is a prerequisite of the creativity and efficiency of virtual teams. Faulty or inadequate information exchange hampers team creativity. Therefore, one of the key challenges of virtual teams is effective communication [16].

Due to the virtual nature of development teams, most of the work process requires various means of electronic communication (see Tabs. 1, 2 and 3). Communication tools can be categorized along four dimensions [16]: time and place, social presence, and information richness. The time dimension refers to the synchronicity of communication. Synchronous communication occurs at the same time, while asynchronous occurs at different times. The dimension of place refers to the location of communication. Co-located communication occurs at the same place, while dispersed communication occurs at different places. Furthermore, the dimension of social presence refers to the level at which a specific communication tool facilitates sensitivity and a personal connection to others, while information richness is defined as "the potential information-carrying capacity of 
data" [16, 17]. Tab. 1 classifies some of the ICT tools according to the above-mentioned four dimensions.

The asynchronous type of communication is characterised by a delay in feedback, which may lead to misunderstandings and miscommunication. Face-to-face interaction is considered the richest form of communication, but for virtual teams limited richness of communications may lead to further misunderstandings. Furthermore, synchronous types of communication offer a higher degree of social presence than asynchronous ones. Social presence is important because it facilitates the feeling of involvement and a sense of interpersonal dialogue [16]. Improvements in processing capabilities and the availability of high speed internet have greatly facilitated the use of synchronous types of communication, especially via videoconferencing.

The communication methods and information contents to be shared within teams are in a strong correlation to the phase of the product development process and each of the tasks requires an appropriate ICT infrastructure [18]. However, the results of some studies have shown that the mere availability of ICTs does not necessarily lead to their use. Therefore, it is essential to establish some standards for the availability and acknowledgement of communication in order to define when dispersed team members should be available for collaboration and how quickly they should respond to the messages [19].

These standards should be specified carefully, since other studies have shown that the frequency of communication has a subtle influence on creativity within the teams. There is an optimal frequency of communication, while too low or too high frequencies can have a negative impact on creativity [20]. For example, a too high frequency may cause unclear information encoding and information overload.

Many studies have also confirmed that different ICT tools have different influences on market performance, innovativeness and product quality, although they mostly do foster the results [21]. For example, e-mail communication has been proved to be an excellent tool for engineering project management and information sharing, but was not that useful as a problem-solving tool $[22,23]$.

Table 1 Types of ICT tools according to four dimensions

\begin{tabular}{|c|c|c|c|c|}
\hline & \multicolumn{4}{|c|}{ Dimensions } \\
\hline Types of communication (tool) & Time & Space & Social presence & Information richness \\
\hline Face-to-face & Same (synchronous) & Same(co-located) & Highest & Richest \\
\hline $\begin{array}{l}\text { Videoconferencing (e.g. Skype-- } \\
\text { audio-video, etc.) }\end{array}$ & Same (synchronous) & Different (dispersed) & High & High \\
\hline $\begin{array}{l}\text { Audioconferencing(e.g. Skype-- } \\
\text { audio, conference phone calls, etc.) }\end{array}$ & Same (synchronous) & Different (dispersed) & Moderate & Moderate \\
\hline $\begin{array}{c}\text { Instant messaging } \\
\text { (e.g. Skype chat, Windows Live } \\
\text { Messenger, Yahoo Messenger, etc.) }\end{array}$ & Same (synchronous) & Different (dispersed) & Moderate & Low \\
\hline Shared workspace(e.g. BSCW) & Different (asynchronous) & Different (dispersed) & Low & Moderate \\
\hline E-mail & Different (asynchronous) & Different (dispersed) & Low & Low \\
\hline Voice mail & Different (asynchronous) & Different (dispersed) & Low & Moderate \\
\hline
\end{tabular}

\section{Further development of vending machines and means of communication within the virtual team}

The milk vending machine (Fig. 3) constitutes one part of a future automatic marketplace that performs one of the phases of the process ranging from hay production to the sale of milk.

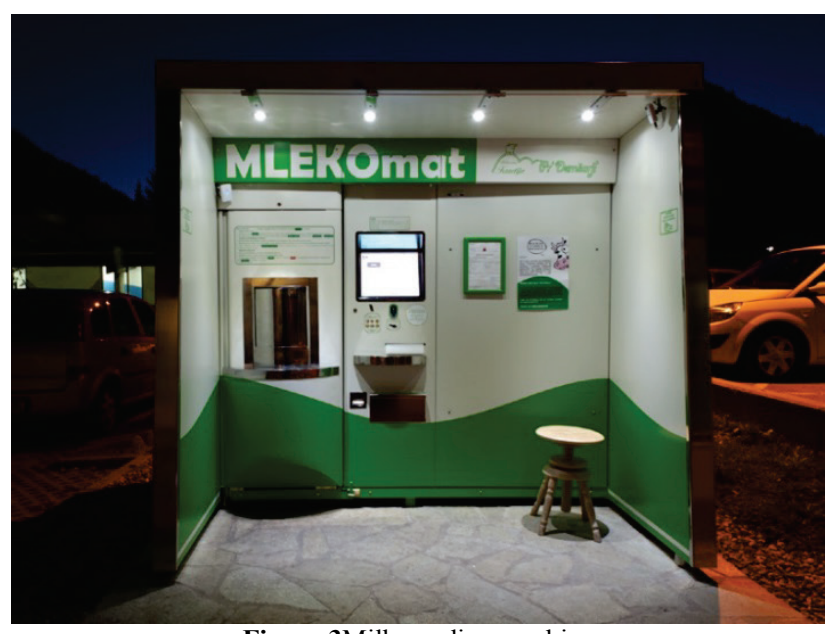

Figure 3Milk vending machine
Based on various analyses (market analysis, trend analysis and analysis of competitive vending machines), the first author designed a mechatronic system whose functions are to be performed by the following modules:

- Module for pouring drinks: This module comprises a cooling system, a container for storing drinks, a pump with a volume meter and a pouring site. The cooling system and the pouring site are common to all types of drinks, while the container with the pump and volume meter for measuring the poured quantities is separate for each type of drink. This vending machine can simultaneously contain 3 different types of drink (currently only raw hay milk is available);

- Module for itemised products: This module comprises a container and a mechanism for dispensing itemised products (i.e. plastic bottles).

- Control module: Contains control electronics with software that connects all other modules into a functional whole and ensures their appropriate functioning.

- Communication module: Provides for (remote) communication with the user and supervisor

- Payment module: Enables payment with cash or with special USB sticks. 
- Housing: Enables mechanical positioning in space and provides protection from the elements and other external influences. The outer design is an integral part of its shape, which has to be both appealing and functional.

Considering the functions of individual modules, it is evident that an interdisciplinary approach was necessary (Tab. 2). The necessary (generic) knowledge had been identified: mechanical engineering, electronics, control engineering, computer engineering and industrial design. From this standpoint, an interdisciplinary team was composed, which also included two postgraduate students. Student participation was chosen because such involvement of students has already been successfully used previously for product portfolio expansion of a metal-processing company [4].

Table 2Competences of virtual team members

\begin{tabular}{|c|c|}
\hline Team members & Specific competences \\
\hline $\begin{array}{l}\text { member } 1 \text { from a } \\
\text { farm (owner) }\end{array}$ & $\begin{array}{c}\text { team management, product development } \\
\text { processes, mechanical concept, } \\
\text { embodiment and detail design, strength } \\
\text { analysis }\end{array}$ \\
\hline $\begin{array}{c}\text { member } 2 \text { from a } \\
\text { company A }\end{array}$ & $\begin{array}{l}\text { web management, PIC software, web } \\
\text { tools for control engineering and testing }\end{array}$ \\
\hline $\begin{array}{c}\text { member } 3 \text { from a } \\
\text { company B }\end{array}$ & $\begin{array}{l}\text { CCA design, manufacturing and testing, } \\
\text { MDB protocol, payment software }\end{array}$ \\
\hline $\begin{array}{l}\text { postgraduate } \\
\text { student }\end{array}$ & $\begin{array}{c}\text { visual communication software design, } \\
\text { PHP, applications of remote access } \\
\text { protocols }\end{array}$ \\
\hline $\begin{array}{l}\text { undergraduate } \\
\text { student }\end{array}$ & $\begin{array}{l}\text { wiring assembly design, selection of } \\
\text { electronic components }\end{array}$ \\
\hline $\begin{array}{l}\text { extended team } \\
\text { member from a } \\
\text { company } \mathrm{C}\end{array}$ & industrial design \\
\hline
\end{tabular}

\subsection{Module for pouring drinks}

The module for pouring drinks was designed as an independent module which can be included in various combinations with other modules. Electrically and informationally, this module is connected to the control module, while mechanically it represents a complete whole, which is inserted in the housing. The module for pouring drinks enables the basic functionality of a vending machine (Fig. 3).

During the development process, communication was largely done via virtual communication means. There was only $25 \%$ of face to face communication, which took place at the initial, intermediary and final joint meeting and during individual partial tests. The most optimal form of communication considering both time and costs was communication via Skype with scanning support (when free hand sketches were necessary for discussions) and sending via e-mail (Table 3). The module for pouring drinks was developed by three members of the development team from the farm, commercial companies and a postgraduate student who conducted an independent task within the module development process. The leader of module development was a team member from the farm who was responsible for mechanical solutions and the development of the basic functionality.

\subsection{Module for itemised products}

The mechanics of the module for itemised products (i.e. plastic bottles) are designed so that they can be used either together with the module for pouring drinks or independently. They are composed of a container which comprises stock checking, a motorised dispenser and a drawer from which buyers receive the purchased plastic bottles.

As with the module for pouring drinks, slightly more face to face communication was needed in the phase of testing the basic functionality. Communication for all of the other development activities was done mainly via Skype (Tab. 3). Three development team members from commercial companies participated in the development of the module for itemised products. The leader of module development was a team member from a commercial company responsible for mechanical solutions and for development of the basic functionality.

\subsection{Control module}

The control module comprises the development of a processor panel with several series of input and output cards. If there is a need for increasing or reducing the number of inputs for switches and sensors, and motor outputs, the panel can be simply upgraded by adding several input and output cards. The system is planned in such a way that the basic processor panel is used for controlling simple mechatronic subsystems, while for more complex mechatronic subsystems a higher capacity computer is added via a USB connection.

The control module consists of a microcontroller and a mini computer running the Linux operation system. The microcontroller performs the task of reading various sensors and controlling the electromechanical part. The two computers communicate via a USB interface. The computer runs the background processes connecting the microcontroller, business logic and user interfaces. The computer is also connected in the network and enables remote access for users (i.e. system supervisors) via various interfaces (e.g. WEB, VNC and terminal access). Users are also able to $\log$ in the system from a remote location to monitor its functioning and diagnose errors in the case of any technical problems. These functionalities facilitate prompt potential software upgrade and reload.The key parameters necessary for system operation are displayed to the user on the remote panel with LCD graphic display. The entire system is designed in such a way that practically all software errors can be eliminated through remote access.

At the beginning of planning, an introductory face to face meeting was held, at which the role of the control module was confirmed and a rough design thereof was produced. A part of the development team then continued with independent work (Tab. 3). The majority of communication was conducted via Skype. It was necessary to harmonise the possibilities for producing electronic circuits and soldering technology with the needed communications between individual parts of the software. Two team members from commercial companies and a postgraduate student participated in the development of this module. The leader of module 
development was a team member from a commercial company who was an expert in control software.

\subsection{Communication module}

The communication between the buyer and the vending machine is done via a touch screen and software installed on the machine. This software offers users simple communication with the vending machine, leading them through the entire process of purchase, payment and dispensing of products. The development of the communication module comprised the development of the procedure for selecting products, procedure for payment of selected products and the procedure for their dispensing (for liquids and plastic bottles).

The designing of the communication procedure between the user and the vending machine comprised the determination of the necessary communication steps, individual information from the vending machine's user for each step and possible connections between these steps. After these procedures were designed, visualisation of the user interface was done for individual steps of the procedure in the form of screen pictures in PPT form. It comprised the general set-up of the interface's functionality (data presentation and possible actions in the form of buttons). The second step of designing the user interface was the design of a simple virtual vending machine: a user interface was made in the form of a web page and a monitoring module to be used for determining the current state of the virtual vending machine. By using the virtual vending machine, it was possible for us to test the functioning of the user interface before its installation on the vending machine for all anticipated states of the vending machine. The third and last step of designing the user interface was its installation in the vending machine and its testing on the machine.

The user interface was customised specifically for use in the vending machine and was also tested by test users prior to its installation on the machine. The test users were chosen with respect to the target groups of vending machine users. The advantage of the customised user interface lies in its adjustment to individual vending machine requirements and the resulting simpler and improved user experience.

The main purpose of developing the above-mentioned virtual vending machine as part of user interface development was to reduce the time required for user interface testing on the machine due to concurrent development of the user interface and other parts of the machine. Another reason was the possibility to perform prompt testing of any corrections and supplements made on the user interface before its installation on the vending machine, which shortened the time of the machine's downtime.

Two team members from commercial companies and a postgraduate student participated in the development of this module. The postgraduate student was the leader of module development. Several different types of complementary knowledge were required. The entire development process, as well as the testing and elimination of any errors, were conducted using various forms of virtual communication. The majority of communication was done via Skype (Tab. 3).

\subsection{Payment module}

The payment module was composed of a coin receiving device, which also served for returning cash, and a payment unit for USB sticks. Communication between them and the control module was done via an MDB protocol. MDB (Multi-Drop Bus) is a protocol intended for communication between various payment systems via a single bus. Communication is sequential with a constant speed of 9600 bits per second. A command sent to the common bus is visible to all machines, but only the one whose address was sent in package with the said command will respond. A single MDB controller can communicate via the bus with a maximum of 32 machines. The MDB protocol is standardised and is regularly updated so as to keep up with the development of new payment systems. Integration of the MDB protocol with the control module's software was done so that each payment system would operate independently, but they may also complement each other if necessary.

A team member from a commercial company, who was also the leader of module development, and a postgraduate student participated in the development of this module. The entire development process, as well as the testing and elimination of any errors, were conducted via various forms of virtual communication. As usual, communication via Skype was used the most (Tab. 3).

\subsection{Housing}

The development of the housing was done concurrently with the development of the other modules. An industrial designer produced several variants of shapes and details and then the most optimal one was chosen based on the functionality, design guidelines and integration in the local environment.

A team member from the company, who was also the leader of module development, an undergraduate student and an external associate in charge of industrial design, participated in the development of this module. In the initial part of development, communication was conducted partially virtually and partially face to face. ICT was used for communication during core development of the module, while face to face communication prevailed during choosing the final industrial design alternative, prototype testing and installation (Table 3).

\subsection{Modular extension into automatic marketplace for agricultural products}

The above-mentioned modules are part of an automatic marketplace for the handling and sale of drinks (for the time being, only hay milk is sold in this way). The other part of the automatic marketplace also has to enable the handling and sale of packed itemised products (e.g. bread, bakery products), as well as temperaturesensitive ones (e.g. eggs, cottage cheese and other types of cheeses, fish etc.) (Fig. 4).

The conceptual design of our vending machine for packed agricultural products was developed after the milk vending machine was already in successful operation. The 
former was developed by the same team and following the same development process (Fig. 2). The percentages of intrateam communication are shown in Tab. 3 .

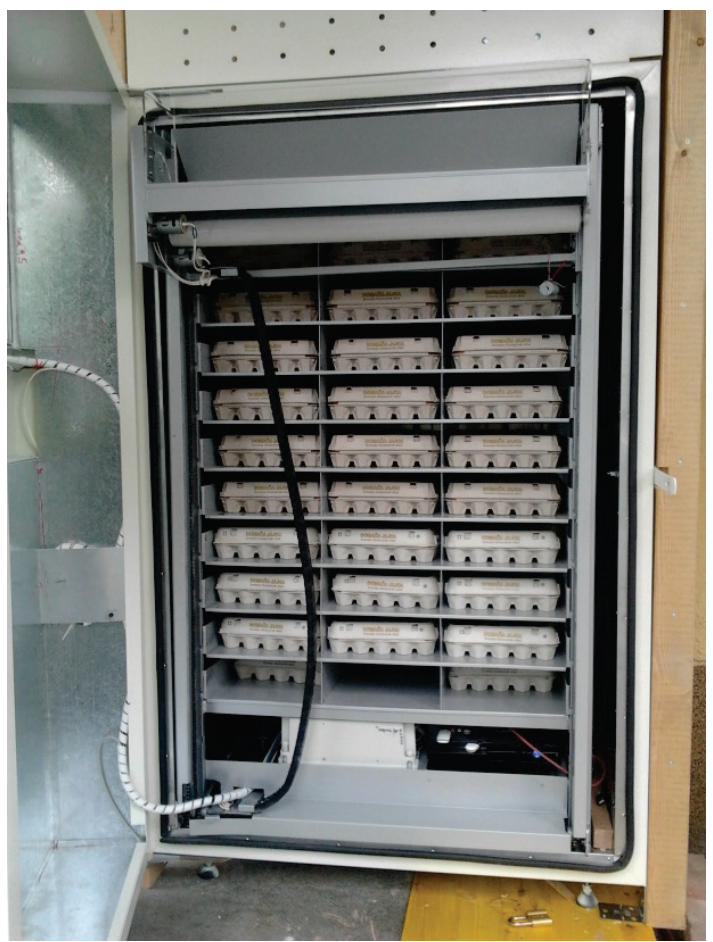

Figure 4 Vending machine for packed agricultural products (packed eggs in this case)

A special feature of this module is the front lift onto which products are pushed from individual shelves. With the product, the lift then moves to the product delivery window which is closed with a small door and an automatic latch. The latch is released upon each transaction, so that the consumer can take the purchased products. Reliable adding of products onto the lift is done using ejection assemblies and the necessary sensors. This module is connected to the central communication module which records all of the operational and statistical data, so that in the case of dispensing errors the machine can return money. Recording of sales and stocks enables the module to operate according to the FIFO (First In, First Out) system.

In addition, it was necessary to upgrade the existing communication and payment modules to combine the sale of drinks and pre-packed products in an automatic marketplace.

\section{Results and discussion}

The result of the virtual development process described above was a modular automatic marketplace for agricultural products (Fig. 5). Its unique features lie in the dosing system, which achieves a precision of $\pm 0,5 \%$, in remote monitoring and diagnosing of the system, in the unified payment module which is common to both vending machines of the automatic marketplace, and in its modular structure. The modular structure enables modules to operate as independent vending machines (e.g. vending machine for selling packed eggs, Fig. 4). The currently used manufacturing technologies were selected primarily by anticipating small batches.

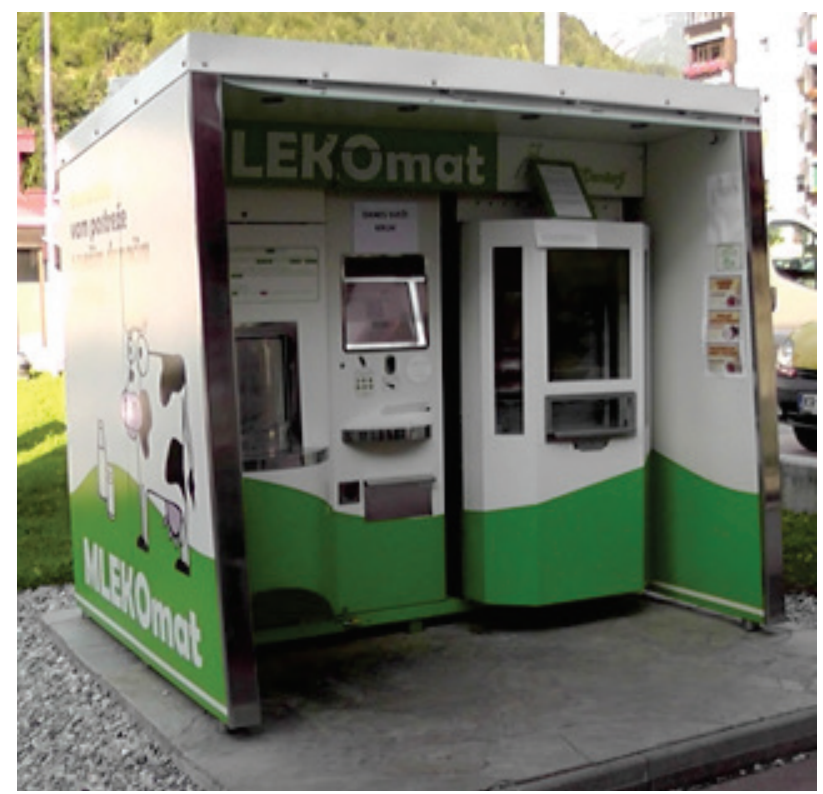

Figure 5 Automatic marketplace (raw milk, packed eggs and bakery products) [5]

Development was conducted according to the process shown in Fig. 2, which is a very simplified variant of the Gausemaier's 3-Cycle-Model [6]. The model in Fig. 2 emphasises the iterative nature of individual process phases and the entire development process.

The process was performed by a virtual interdisciplinary team whose members had the necessary technical and professional competencies. The majority of communication within the team $(86 \%$, Tab. $2,92 \%$, Tab. 3 ) that was necessary for development was conducted via the use of ICT. This is understandable, as it is necessary to provide an appropriate substitute for communication that is normally characteristic of collocated teams. The predominant percentage of using video and voice calls (44 $\%$ of all the communication during the developmental process for the milk vending machine (Tab. 2) and $40 \%$ for the vending machine for packed products and its integration into automatic marketplace (Tab. 3); in both cases done via Skype) is also understandable, as they represent the synchronous type of communication, which is the best approximation for face-to-face communication. E-mails (asynchronous type of communication) were used only in $8 \%$ during development of the milk vending machine and $15 \%$ in case of the vending machine for packed products (Tabs. 3, 4, respectively).

This is in line with Kock's work on media naturalness of various communication means; humans are not well adapted to employ communication tools that suppress synchronicity and support for speech-enabled communication. Synchronicity is one of the key elements of media naturalness, especially when communication of knowledge is the goal [24]. Naturally, this only applies under the assumption that high-quality communication infrastructure is available, along with mastery of the relevant ICT tools. However, regardless of the intense use of communication technologies, primarily video/audio calls, these could not fully replace standard face-to-face interaction. For virtual teams, face-to-face meetings are generally needed early in the course of team formation, e.g. for assigning team roles, specifying goals and 
building initial trust [16]. This was important, as one of the necessary conditions to achieve and maintain a high level of team creativity is the trust amongst all team members. For example, Thompson [25] has shown that in uncertain and complex conditions requiring mutual adjustment (which is characteristic for product development), effective and sustained action is only possible where there is mutual trust [26]. Similarly, IJsendoorf found out that personal acquaintances before the beginning of collaboration are regarded as stimulative for virtual teams in industrial environments [27].

Table 3Percentages of individual types of communication for the specific modules and the entire (milk) vending machine development process

\begin{tabular}{|l|c|c|c|c|c|}
\hline & Face to face / \% & $\begin{array}{c}\text { Skype - video and } \\
\text { voice calls } / \%\end{array}$ & $\begin{array}{c}\text { Skype - messages } \\
/ \%\end{array}$ & E-mail / \% & Cellular phone / \% \\
\hline Module for pouring drinks & 25 & 45 & 5 & 5 \\
\hline Module for itemised products & 15 & 45 & 20 & 5 \\
\hline Control module & 15 & 40 & 25 & 10 \\
\hline Communication module & 0 & 50 & 25 & 15 \\
\hline Payment module & 0 & 55 & 20 & 5 \\
\hline Housing & 30 & 25 & 24 & 10 \\
\hline Vending machine as a whole & 14 & 44 & 15 & 5 \\
\hline
\end{tabular}

It should be noted that in our case individual team members had previously successfully cooperated on other projects, so that face-to-face meetings were not needed in the phase of team formation. It was very important that basic communication practices, work attitude, observance of time limits, responsibility for adopted decisions, and commitment to the team goals were consistently high. The same was true of the team member motivation.

The greatest percentage of video/voice calls and the absence of face-to-face meetings were recorded during the development of the communication and payment modules for the milk vending machine (Tab. 2). It is believed that the main reasons for this were the low level of interdisciplinarity which characterised the development of these modules and the high degree of professional fit between the team members responsible for their development. The development work was also supported by remote access to the modules (e.g. remote control, installation/running of applications, file transfer and analysis of $\log$ files). A similar pattern was also observed during the development of the vending machine for packed products (Tab. 4).

The lowest percentage of video/voice calls and the highest percentage of face-to-face meetings were recorded during the development of the housing for the milk vending machine (Fig. 2, Tab. 3), which practically also represents the housing for the automatic marketplace. This can be explained by the fact that the evaluation of industrial design was highly subjective (detailed requirements were not provided in advance) and also associated with communication rich interactions between the industrial designer and the farm owner when choosing from among the proposed alternative solutions. The final physical integration of the modules into the housing was also done during this phase.

The sum of face-to-face (25\%) and Skype (video/audio $45 \%$ ) communication was the highest during the development of the module for pouring drinks. This module was also used as the core module for the milk vending machine, and the thorough understanding of its operational concept was of crucial importance in the development of the entire milk vending machine.

An analogous process took place during the development of the module for packed products. The sum of the percentages of face-to-face and Skype (video and voice) communication was the highest in this case (Tab. 4 ), and the percentage of face-to-face communication was also very high. The module was the core module of the vending machine for packed products. In mechanical terms, it was relatively complex and a thorough understanding of its operation was again crucial for further development of the vending machine for packed products.

It is believed that in both cases of core module development the obtained percentages of communication types were the result of the relatively high level of necessary interdisciplinarity (as all team members were intensely involved in the development of both modules). This in turn necessitated a higher percentage of the most information rich types of communication. The finding that creative efforts cannot be accomplished without the opportunity for rich, synchronous interactions should also be noted, as successful new product development undoubtedly requires such efforts [16].

Table 4 Percentages of individual types of communication for the specific modules and the entire vending machine (for packed products) development process

\begin{tabular}{|c|c|c|c|c|c|}
\hline & Face to face $/ \%$ & $\begin{array}{c}\text { Skype - video } \\
\text { and voice calls / } \\
\%\end{array}$ & $\begin{array}{c}\text { Skype - } \\
\text { messages / \% }\end{array}$ & E-mail / \% & $\begin{array}{c}\text { Cellular phone / } \\
\%\end{array}$ \\
\hline Module for packed products & 40 & 20 & 30 & 5 & 5 \\
\hline Control module & 0 & 50 & 25 & 15 & 10 \\
\hline Communication module - upgrade & 0 & 45 & 30 & 15 & 10 \\
\hline Payment module - upgrade & 0 & 55 & 25 & 5 & 15 \\
\hline Housing & 0 & 30 & 20 & 35 & 15 \\
\hline $\begin{array}{l}\text { Vending machine for packed } \\
\text { products as a whole }\end{array}$ & 8 & 40 & 26 & 15 & 11 \\
\hline
\end{tabular}


The authors believe that a systematic development process is also one of the key elements to achieve expected results via the use of virtual teams, and it includes: appropriate preparation of the requirements list, development of the technical process and function structure, and prompt reporting of any encountered problems/outcomes/decisions. Good planning facilitates the designing/assigning of tasks and the management/autonomy of (sub)teams [28, 29].

Use of ICT significantly reduced the negative effects of geographic dispersion of individual team members. Therefore, the two students were also able to participate on an entirely equal basis and it was only necessary to adjust the timing of virtual meetings in order not to interfere with their study obligations.

Concerning the benefits for the students included in the virtual team, it should be noted that project-based learning is one of the most suitable pedagogies for learning engineering design [18, 30, 31]. Project-based learning addresses transfer of knowledge, which may be defined as the ability to extend what has been learned within one context to other, new contexts $[32,33]$. This is an important component of engineering competency development [34]. Emerging evidence suggests that project-based learning encourages and supports collaborative work [18]; it also improves retention and enhances design thinking [31].

In short, the presented case indicates that virtual team members should have appropriate technical and professional competencies. They should have an introductory face-to-face meeting (if they have not collaborated previously), they should have good command of ICT use and should follow a systematic developmental process. These findings (although based on a limited scale) are in line with the findings of many virtual team studies, e.g. [27, 29, 35].

One should be aware of the specifics of the virtual team: there were no differences in cultural backgrounds between virtual team members, no time differences in terms of time zones, no differences in levels of technological proficiency and no foreign language issues. It has been indeed reported that these types of issues create barriers within virtual teams $[16,28]$. Besides, the team members have successfully collaborated previously, although not virtually.

It is also important to be aware of one's limitations in interpreting the reasons for the percentages of individual types of communication used during the development process. The results were obtained during real virtual product development with a specific virtual team. These case specific results cannot be generalised for general virtual product development teams.

In order to generalise our interpretations of the obtained percentages, which were also based on our experience from monitoring of development processes for various products [36, 37, 38, 39], we would need even more observations of various product development processes.

\section{Conclusion}

Two methods developed in academia were used in the presented work, namely the method of searching for new product opportunities and a highly simplified Gausemaier's 3-Cycle-Model for the development process of mechatronic products. The described case indicates that it is possible to search for opportunities for product development in a systematic manner. It is believed that the case also demonstrates that a virtual development team which systematically performs the development process using ICT is capable of efficiently achieving the planned project objectives.

The development of the automatic marketplace took place only because of the availability of virtual collaboration as alternative. Otherwise, it is strongly believed that the development time would be much longer and costlier due to hampered information exchange, limited team members' availability and consequent harmonisation of their available time slots, and additional travel costs.

The identified opportunity (i.e. the production of hay milk and its direct sale via the developed automatic marketplace) has been proved to be quite promising. It has enabled the farm owner to achieve much higher milk prices than he would have been able to get by selling it to the dairy as is customary (EUR 1 instead of EUR 0,35). In case of eggs, $50 \%$ higher earnings per egg were achieved.

Study findings on working in virtual teams have thus been confirmed. This is because such teams employ ICT, the four dimensions of which are the closest to the dimensions of face-to-face communication, especially video-conferencing.

In our case, the inclusion of students proved to be very effective, as they functioned as equal virtual development team members. Last but not least, it is important to note that through student participation in such projects, companies are able to get to know their potential new human resources and students are also able to familiarise themselves with potential employers.

ICT is accessible (hardware, software, data transfer services) and virtual development teams are suitable for work on those projects for which companies do not have all of the necessary human resources available at one location. SME (Small and Medium Enterprises) in particular are generally faced with a lack of suitable human resources and it is believed that in such cases the formation of virtual development teams (composed of e.g. company expert(s), students and academics having complementary competences) is a good solution.

\section{References}

[1] Krznar, J. J.; Belec, A. Sampling of cultivated areas and livestock: methodology. // Report No. 7, Statistical Office of the Republic of Slovenia, 2004.

[2] Benedičič, J.; Duhovnik, J.; Žavbi, R. Innovations for Future Development of Farms: a Case Study of the Implementation of an Opportunity Search Method on a Farm. // Transactions of the ASABE. 54, 2(2011), pp. 743752. DOI: $10.13031 / 2013.36477$

[3] Benedičič, J.; Žavbi, R.; Duhovnik, J. Development of a new method of searching a new product development opportunity. // Tehnički vjesnik-Technical Gazette. 19, 4(2012), pp. 759-767.

[4] Žavbi, R.; Benedičič, J.; Duhovnik, J. Use of mixed academic-industrial teams for new product development: delivering educational and industrial value. // International 
Journal of Engineering Education. 26, 1(2010), pp. 178194.

[5] Benedičič, J.; Krek, J.; Leben, V.; Velez Vörös, G.; Beravs, T.; Potočnik, S.; Žavbi, R. Development of a vending machine using virtual collaboration. // Proceedings of the DESIGN2014 Conference / Cavtat, 2014, pp. 131-140.

[6] Gausemeier, J.; Dumitrescu, R.; Kahl, S.; Norsiek, D. Integrative development of product and production system for mechatronic products. // Robotics and ComputerIntegrated Manufacturing. 27, 4 (2011), pp. 772-778. DOI: 10.1016/j.rcim.2011.02.005

[7] Pečjak, V. Ideation: creative techniques in companies, schools and elsewhere. self-published, 1990 (in Slovenian).

[8] Lipnack, J.; Stamps, J. Virtual teams: People working across boundaries with technology. 2nd ed. Wiley, New York, 2000.

[9] Paul, S.; Seetharaman, P.; Samarah, I.; Mykytyna, P. P. Impact of heterogeneity and collaborative conflict management style on the performance of synchronous global virtual teams. // Information and Management. 41, 3(2004), pp. 303-321. DOI: 10.1016/S0378-7206(03)00076-4

[10] Kayworth, T.; Leidner, D. The global virtual manager: A prescription for success. // European Management Journal. 18, 2(2000), pp. 183194. DOI: 10.1016/S0263-2373(99)000900

[11] Fain, N.; Kline, M.; Duhovnik, J. Is new product development culturally bound? // Proceedings of the International conference on engineering and product design education / London, 2011, pp. 715-720.

[12] Žavbi, R.; Tavčar, J. Preparing undergraduate students for work in virtual product development teams. // Computers \& Education. 44, 4(2005), pp. 357-376. DOl: 10.1016/j.compedu.2004.02.007

[13] Žavbi, R.; Vukašinović, N. A Concept of AcademiaIndustry Collaboration to Facilitate the Building of Technical and Professional Competencies in New Product Development. // International journal of engineering education. 30, 6 (2014), pp. 1562-1578.

[14] Allan, M.; Chisholm, C. U. The Development of Competencies for Engineers within a Global Context. Proceedings of the Conference on Innovation, Good Practice and Research in Engineering Education. 2008. http://www.heacademy.ac.uk/assets/documents/subjects/en gineering/EE2008/p001-allan.pdf. (14.08.2013).

[15] Tavčar, J.; Žavbi, R.; Verlinden, J.; Duhovnik, J. Skills for effective communication and work in global product development teams. // Journal of Engineering Design. 16, 6(2005), pp. 557-576. DOI: 10.1080/09544820500273797

[16] Nemiro, J. E. Creativity in Virtual Teams. Pfeiffer, San Francisco, 2004.

[17] Daft, R. L.; Lengel, R. H. Information richness: A new approach to managerial behaviour and organization design. // Research in Organizational Behavior / B. M. Staw and L. L. Cummings. Greenwich, Conn.: JAI Press, 1984, pp. 191233.

[18] Christophersen, E.; Coupe, P. S.; Lenschow, R. J. Townson, J. Evaluation of Civil and Construction Engineering Education in Denmark. Centre for Quality Assurance and Evaluation of Higher Education in Denmark, Copenhagen, 1994.

[19] Montoya, M. M.; Massey, A. P.; Caisy Hung, Y-T.; Crisp, C. B. Can you hear me now? Communication in Virtual Product Development Teams. // The Journal of product innovation management. 26, 2(2009), pp. 139-155. DOI: 10.1111/j.1540-5885.2009.00342.x

[20] Leenders, R. Th. A. J.; van Engelen, J. M. L.; Kratzer, J. Virtuality, communication, and new product team creativity: a social network perspective. // Journal of Engineering and Technology Management. 20, 1-2(2003), pp. 69-92.
[21] Durmusoglu, S. S.; Barczak, G. The use of information technology tools in new product development phases: Analysis of effects on new product innovativeness, quality, and market performance. // Industrial Marketing Management. 40, 2(2011), pp. 321-330. DOI: 10.1016/j.indmarman.2010.08.009

[22] Wasiak, J.; Hicks, B.; Newnes, L.; Loftus, C.; Dong, A.; Burrow, L. Managing by E-Mail: What E-Mail can do for engineering project management. // IEEE Transactions on engineering management. 58, 3(2011), pp. 445-456. DOI: 10.1109/TEM.2010.2090160

[23] Farris, G. F.; Hartz, C. A. ; Krishnamurthy, K.; McIlvaine, B.; Postle, S. R.; Taylor, R. P.; Whitwell, G. E. Webenabled innovation in new product development. // Research Technology Management. 46, 6(2003), pp. 24-35.

[24] Kock, N. Designing E-Collaboration Technologies to Facilitate Compensatory Adaption. // Information Systems Management. 25, 1 (2008), pp. 14-19. DOI: 10.1080/10580530701777115

[25] Thompson, J. D. Organizations in action. McGraw-Hill, New York, 1967

[26] Dayan, M.; Di Benedetto, A. The impact of structural and contextual factors on trust formation in product development teams. // Industrial Marketing Management. 39, 4(2010), pp. 691-703. DOI: 10.1016/j.indmarman.2010.01.001

[27] IJsendoorf, H. Application of computer aided systems. PD\&E Automotive. E-GPR Industrial case study, 2002.

[28] Daim, T. U.; Ha, A.; Reutiman, S.; Hughes, B.; Pathak, U.; Bynum, W.; Bhatla, A. Exploring the communication breakdown in global virtual teams. // International Journal of Project Management. 39, 2(2010), pp. 199-212.

[29] Oguntebi, J. O. Creating Effective Global Virtual Teams: A Transactive Memory Perspective. Doctoral Dissertation. The University of Michigan, 2009.

[30] National Science foundation; Action Agenda for Systemic Engineering Education Reform, NSF 98-27. 1998. http://www.nsf.gov/pubs/1998/nsf9827/nsf9827.pdf. (15.7.2014.)

[31] Dym, C. L.; Agogino, A. M.; Eris, O.; Frey, D. D.; Leifer, L. J. Engineering Design Thinking, Teaching, and Learning, Engineering Design Thinking, Teaching, and Learning. // Journal of Engineering Education. 94, 1(2005), pp. 103-120. DOI: 10.1002/j.2168-9830.2005.tb00832.x

[32] Bransford, J. D.; Brown, A. L.; Cocking, R. R. (eds.) How People Learn: Brain, Mind, Experience and School. National Academy Press, Washington, D. C., 1999.

[33] Singley, M. K.; Anderson, J. R. The transfer of cognitive skill. Harvard Univ. Press, Cambridge, MA, 1989.

[34] Byrnes, J. P. Cognitive Development and Learning in Instructional Contexts. Allyn and Bacon, Boston, Massachusetts, 1996.

[35] Rezgui, Y. Exploring virtual team-work effectiveness in the construction sector. // Interacting with Computers. 19, 1(2007), pp. 96-112. DOI: 10.1016/j.intcom.2006.07.002

[36] Fain, N.; Kline, M.; Vukašinović, N.; Duhovnik, J. The impact of management on creativity and knowledge transfer in an academic virtual enterprise. // Tehnički vjesnikTechnical Gazette. 17, 3(2010), pp. 347-351.

[37] Vukašinović, N.; Fain, N.; Duhovnik, J. The influence of a company's strategy on creativity and project results in an NPD - case study. // Int. Conference on Engineering Design / København, 2011, pp. 1-7.

[38] Vukašinović, N.; Fain, N. A decade of project based design education: is there a future? // Proceedings of the DESIGN2014 Conference / Cavtat, 2014, pp. 1441-1450.

[39] Žavbi， R.; Kolšek, T.; Duhovnik, J. Virtual product development study courses - evolution and reflections. // Int. Conference on Engineering Design / Stanford, 2009, pp. 113-124. 


\section{Authors' addresses}

Janez Benedičič, Ph.D.

University of Ljubljana

Faculty of Mechanical Engineering

Aškerčeva 6, SI-1000 Ljubljana, Slovenia

\section{Janez Krek, Ph.D. student}

University of Ljubljana

Faculty of Mechanical Engineering

Aškerčeva 6, SI-1000 Ljubljana, Slovenia

\section{Vilko Leben}

P-ino d.o.o.

Martinj Vrh 24, SI-4228 Železniki, Slovenia

\section{Gusztav Velez, Vöros}

P-ino d.o.o.

Martinj Vrh 24, SI-4228 Železniki, Slovenia

\section{Tadej Beravs, Ph.D.}

University of Ljubljana

Faculty of Electrical Engineering

Tržaška cesta 25, SI-1000 Ljubljana, Slovenia

\section{Simon Potočnik}

P-ino d.o.o.

Martinj Vrh 24, SI-4228 Železniki, Slovenia

Roman Žavbi, Dr., Assoc. Prof. (corresponding author)

University of Ljubljana

Faculty of Mechanical Engineering

Laboratory for Engineering Design - LECAD

Aškerčeva 6, SI-1000 Ljubljana, Slovenia

Tel.: +38614771412

Fax: +38614771 156

E-mail: roman.zavbi@lecad.fs.uni-lj.si 